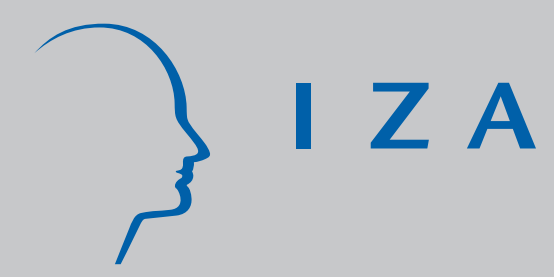

IZA DP No. 883

Overeducation, Wages and Promotions within the Firm

Sandra Groeneveld

J oop Hartog

October 2003 


\title{
Overeducation, Wages and Promotions within the Firm
}

\author{
Sandra Groeneveld \\ ISEO, Erasmus University Rotterdam \\ Joop Hartog \\ SCHOLAR, University of Amsterdam, \\ Tinbergen Institute, CESifo, AIAS and IZA Bonn
}

Discussion Paper No. 883
October 2003

IZA

P.O. Box 7240

D-53072 Bonn

Germany

Tel.: +49-228-3894-0

Fax: +49-228-3894-210

Email: iza@iza.org

This Discussion Paper is issued within the framework of IZA's research area The Future of Labor. Any opinions expressed here are those of the author(s) and not those of the institute. Research disseminated by IZA may include views on policy, but the institute itself takes no institutional policy positions.

The Institute for the Study of Labor (IZA) in Bonn is a local and virtual international research center and a place of communication between science, politics and business. IZA is an independent, nonprofit limited liability company (Gesellschaft mit beschränkter Haftung) supported by Deutsche Post World Net. The center is associated with the University of Bonn and offers a stimulating research environment through its research networks, research support, and visitors and doctoral programs. IZA engages in (i) original and internationally competitive research in all fields of labor economics, (ii) development of policy concepts, and (iii) dissemination of research results and concepts to the interested public. The current research program deals with (1) mobility and flexibility of labor, (2) internationalization of labor markets, (3) welfare state and labor market, (4) labor markets in transition countries, (5) the future of labor, (6) evaluation of labor market policies and projects and (7) general labor economics.

IZA Discussion Papers often represent preliminary work and are circulated to encourage discussion. Citation of such a paper should account for its provisional character. A revised version may be available on the IZA website (www.iza.org) or directly from the author. 
IZA Discussion Paper No. 883

October 2003

\section{ABSTRACT}

\section{Overeducation, Wages and Promotions within the Firm*}

We analyse data from personnel records of a large firm producing energy and telecommunication and test for the effect of deviations between required and attained education of workers. Required education is measured as hiring standards set by the firm. We find the usual effects of over- and undereducation in a wage regression, thus rejecting the argument that such effects are exclusively due to firm fixed effects. Distinguishing, within the firm, between a sheltered internal labour market and an exposed external labour market, we find that at the internal labour market over- and undereducation significantly affect career development, in particular at younger ages, but that such effects are mostly absent at the firm's external labour market.

JEL Classification: J31, J41, M51

Keywords: $\quad$ education, wages, overeducation, career mobility, promotions

Corresponding author:

Sandra Groeneveld

Institute for Sociological and Economic Research (ISEO)

Erasmus University Rotterdam

P.O. Box 1738

3000 DR Rotterdam

The Netherlands

Tel.: +31 104088669

Fax: +31 104089141

Email: sgroeneveld@few.eur.nl

\footnotetext{
* Comments on a draft by Pieter Gautier and Hessel Oosterbeek are gratefully acknowledged. The comments given by two referees were quite valuable to improve the focus of the paper.
} 
There is a substantial and still growing literature on 'overeducation', or, more generally, the relation between a worker's attained level of schooling and the schooling required in his or her job. In a loose sense, this literature is akin to the hedonics literature, focusing on matching between worker quality and job requirements to analyse earnings functions. In contrast to the hedonic approach, however, the overeducation literature does not embrace a general labour market equilibrium model. Also, it focuses solely on education, not on other variables.

The overeducation literature is interesting for the empirical regularities that have been found in many studies applying to several countries (Hartog, 2000; Groot and Maassen van den Brink, 2000). First, in an earnings function separately containing required, over- and undereducation (the ORU specification), the returns $\boldsymbol{\omega}$ required education are higher than on attained education in the usual Mincer specification. Returns to a year of overeducation are positive but smaller than on a year of required education. And there is a penalty for years undereducated, but this penalty is also smaller than the return on required education.

We add to this literature in two ways. First, we measure required education from the hiring standards set by the firm, a measure not used before in this literature. Second, we use data from a single firm and so combine the overeducation literature with the analysis of an internal labour market. As far as we know, analysis of overeducation has never been applied within a single firm. The empirical regularities just noted all relate to effects found across the labour market. It's conceivable that the results are due at least to some extent to selective matching of workers and firms. This is indeed what Gautier, Van den Berg, Van Ours and Ridder (2002) claim. In their view, wage effects of overeducation are due mainly to sorting of workers across firms. When firm-job complexity fixed effects are included in the earnings function, the effects of education for a given level of job complexity are no longer significant. Hence, by considering data for a single firm, as we do here, we can test whether the results of the overeducation literature are a pure market effect, arising from interfirm differences in wage and job assignment policies, or whether these results also obtain within an individual firm. If so, the effects observed in the labour market at large may be seen as mirroring effects within single firms.

The ORU literature has not come up with a generally accepted theoretical explanation for the results. As discussed in Hartog (2000), explanations have been sought in the assignment or hedonic theory, in search theory and in human capital theory. The relation with assignment theory is strenuous. Search theory predicts that 
overeducation should decline with age (experience), while the relation with tenure is ambiguous; the predictions are generally upheld empirically. Human capital theory holds that individuals who are overeducated for their job have made a deliberate investment decision: they choose this job because it provides better than average learning opportunities, which will pay off later in the career (Sicherman, 1991). Our dataset allows to test the latter hypothesis for learning (and pay-off) within the same firm, because the data include records of the individual's career within this firm. And because the firm consists of two sections, one more sensitive to the outside labour market conditions than the other, we can even distinguish between effects in an internally and in an externally oriented labour market.

The remainder of this paper has four sections. Below, we introduce the dataset. We then estimate ORU earnings functions and we test the human capital investment hypothesis in the following section. Section 5 concludes.

\section{$2 \quad$ A company database}

For the purpose of testing the hypotheses mentioned above we make use of data from an energy and telecommunications concern, that we label 'Energy'. The company went through major changes in the period under survey (1995-1998) as a result of the liberalisation of the energy market. In the period under review Energy's reaction to this was on the one hand the development of new products and services that are commercially viable, while on the other hand it meant that the 'old' energy sections were increasingly forced to work on a more commercial basis.

Broadly speaking, Energy comprises at the time three different kinds of work units, namely: central staff sections, utility or energy sections and commercial sections. On account of the rules and procedures that determine the selection and promotion decisions, we count the energy sections as part of Energy's internal labour market. According to these rules hiring is biased in favour of internal candidates compared to external candidates and promotion decisions are made according to length of service rather than to performance. This so called internal labour market is less sensitive to external market conditions despite the pressure mentioned above. The internal labour market consists of rather bureaucratic units that until recently were operating as public utility companies. Moreover, on the internal labour market firm specific qualifications are more important than on the external labour market. We classify the commercial sections as part of the external labour market, since these are far less subject to the rules. In addition they are more externally oriented than the energy sections. The 
commercial sections operate on an open commercial market and as a result experience severe competition. Comparison of the two markets that are part of the same holding, enables us to make a controlled comparison of employees' careers on the internal and external labour market.

We had the opportunity of intensive data collection, which leads to unusually high accuracy and reliability of the measurements. The fact that we gained access to a large amount of data makes it possible to chart accurately the working of Energy's internal labour market (see Groeneveld, 2002). Data collection was extensive, varying from collecting policy documentation and the data from the personnel and payroll archives to information from interviews with employees.

The personnel information system comprises information on personnel characteristics such as age, sex, marital status and education (level, field of study, number, year), job characteristics such as level (scale, required education) and field, salary, and work unit for each employee. Information on education, jobs, salary and work unit runs from date of entrance into the company to December 1998, as every mutation is registered. Data is available for each individual who is employed between 1995 and 1998. Some descriptive statistics for the period 1995-1998 are presented in Table 1. Note that the table is restricted to those who are employed during this whole period: 2704 employees. Employees who entered the company and those who left in this period are excluded from the analysis.

- Table 1 --

Table 1 shows that on the so-called internal labour market workers earn less than those on the external labour market. In 1995, average required education was equal in both labour markets, but by 1998, it had fallen more in the internal labour market than in the external labour market. Attained education, by contrast, slightly increased. Relative wage growth between 1995 and 1998 is substantially larger in the external labour market. On the external labour market one out of five workers is promoted to a higher wage level compared to one out of eight on the internal labour market. When we take a look at job shifts, the difference between the segments is even larger. On the external labour market 34 percent of the workers is promoted to a higher job level compared to 14 percent on the internal labour market. At first sight this is remarkable, as we expect more promotions on the internal than on the external labour market. However, this may very well relate to the tight situation in the 
outside labour market to which the firm's external labour market is linked. The difference in average tenure on the present job does match anticipations: it is substantially longer in the internal labour market than in the external labour market. With equal number of positions held and average ages also close, this suggests a rather different distribution of tenure distributions between the segments: more unequal in the internal han in the external labour market.

Almost one out of five employees is overeducated and one out of seven is undereducated (see next section for definitions). The difference between the two markets is large: in 1998 on the external labour market three out of ten employees is overeducated, whereas on the internal labour market only 13 percent is overeducated. In both segments the percentage slightly drops between 1995 and 1998. As regards undereducation the differences between the segments are substantially smaller.

It is important to compare the employees who left the company between 1995 and 1998 with the ones who stayed on relevant characteristics. However, there is only sparse information on the workers who left the company. We are unable to distinguish between quitters from the external and from the internal labour market segment. Of those who left almost two thirds had a technical job compared to more or less half of those who stayed. Departure from commercial and administrative jobs is relatively modest: only fifteen percent of the workers who left compared to 25 percent of those who stayed. Average job level and educational level are more or less equal for both. Employees who left the company are on average four years younger than those who

stayed. In addition, they spent on average fewer years with the company: 13.5 compared to 16 years for those who stayed. Of those who left between 1995 and 1998, 25 percent were overeducated, as against 19 percent of those who stayed. For undereducation, the share was 12 percent among those who left and 14 percent among those who stayed. Hence, overeducation may be a slight stimulus to departure, while undereducation is no clear brake.

\section{$3 \quad$ ORU as a firm wage effect?}

Analyses in this section are based on the dataset with those employed per ultimo 1998. So, employees who entered the company after 1995 are now included. We use OLS regression analysis with the gross monthly wage as dependent variable. Taking the gross wage we avoid the effect of possible changes in marit al status for the income tax and hence, net income. Wages are expressed in full time equivalents. We know for every individual 
standard working hours, as a fraction of the full-time contract (i.e. a 0.5 or a 0.8 contract) and use this to standardise wages. We ignore overtime hours and the associated pay. Generally, men work full-time and only women have part-time contracts.

With respect to the independent variables in the model the following remarks can be made. Firstly, we use age rather than experience as it is well measured, whereas experience can only be estimated from age minus probable age of having left school. Secondly, required education is measured as the indication used in hiring by the personnel department of the organisation. As far as we know, this measure has not been used in the literature. It seems fair to assume that the personnel department, fed by management, has good information on technically required qualifications for a particular job. It is quite conceivable that hiring standards are set also with an eye on market conditions, for example benefiting from excess supply of higher educated to raise the quality of workers at a given job level. One might then still expect wages to reflect the (expected) marginal productivity of these workers in the jobs for which they are hired. In fact, from our fieldwork within the company we know that managers have no preference for overeducated workers and do not explicitly seek to hire them (see Groeneveld, 2002: 162 for details).

Thirdly, overeducation is measured as the difference between actual and required education, with negative values set equal to zero; undereducation is defined similarly. The education variables are all measured in years. Control variables we include are gender (dummy for female), number of training courses taken, type of education and number of job positions held within this firm.

- Table 2 -.

The results in Table 2 confirm the regularities usually found in the ORU literature. Required education has a higher return than attained education in the Mincer specification, the premium on overschooling and the penalty on underschooling are both statistically significant and smaller than the returns on required education. Hence, we have extended the conclusion that these results are not sensitive to the way required education has been measured (Hartog, 2000): they now also apply to the use of hiring standards. In contrast to the other results in the literature, the correlation coefficient increases strongly if we replace attained education by required education. For example, in results for the Netherlands (Hartog and Oosterbeek, 1988) or Germany and the US 
(Daley, Büchel and Duncan, 2000), the increase in the correlation coefficient is only modest. Getting closer to actual firm practice also improves the explanatory power of the approach.

We have also established that the common results apply within a single firm. This is of course far from claiming that they will apply within each and every firm. But at least they cast doubt on the claim that the results are fully explained from sorting of workers across firms. The sorting explanation is promoted by Gautier, Van den Berg, Van Ours and Ridder (2002) (GBOR). They find that "new workers with a relatively high education earn about the same as their colleagues at the same job level at the same firm in the same year" (p.534), and take issue with the common finding of a positive return to surplus schooling. ${ }^{1}$ GBOR estimate an earnings function including fixed effects for job level by firm and the effect of education separately by job level. They restrict their sample to workers with tenure below one year, to avoid problems with endogenous tenure. Certainly, endogenous tenure may generate selectivity effects, but it is not clear in which direction. With voluntary worker mobility, the observed effect of tenure on overeducation may go both ways. For a worker with given education, required education (job level) is determined by opposing forces. Good present job offers survive, leading to high job levels for high tenure. But good outside offers draw workers away, generating high job levels for low tenures (Hartog, 2000a; Garen 1988). Overeducation and its earnings consequences cannot unambiguously be related to selective mobility.

We must admit that we are not fully convinced of the reliability and robustness of the estimates reported by GBOR. They report a zero effect of schooling at given levels of job complexity once the fixed effects have been taken into account. Their fixed effects cover firm-job complexity-time: a fixed term for each of the four years in their sample, for each of their roughly 1500 firms, for each of the 6 job complexity levels. The bulk of their observations work at job levels 2, 3 and 4, which make the results for 1, 5 and 6 less reliable for simple want of observations $^{2}$. For the remaining three job levels they have on average only just over 5 observations per fixed effect and then find that for two of the job levels, education does have a significant effect (one negative and one positive). If they ignore job levels altogether and include firm fixed effects, they find that education is

\footnotetext{
1 Admittedly, GBOR do not analyse overeducation, but they do state conclusions in these terms. In an accompanying working paper GBOR (1998) measure overeducation by comparing the level of education of every individual worker and the mean level of education of his direct colleagues working at the same job level, and get the same results: workers with relatively many years of sch ooling at given job complexity levels do not earn more at these jobs than their colleagues working in the same jobs, once fixed effects are taken into account. Hence, differences between their and our results are not due to differences in specification.

${ }^{2} \mathrm{We}$ are grateful to Pieter Gautier for providing additional information on the points discussed here.
} 
insignificant. This may be related to firm stratification by education levels (i.e. modest variation of education levels within firms relative to variation between firms) and by other variables picking up some effect of education, although we cannot assess to what extent this is the case. Thus, we have some doubts on the strength of their result. In our view, the possibility that the common ORU results found across labour markets mirror relations that hold within single firms is still wide open ${ }^{3}$. Admittedly our own results apply only to a single firm ${ }^{4}$, and we cannot rigorously adhere to the rule that "all swans are white" is refuted by finding a single black swan. But the case that the common result of a wage premium for overeducation is mainly due to selective matching of workers to firms has not convincingly been made.

Note that the ORU specification (model 3) in comparison to the Mincer specification also affects other coefficients: the effect of training courses drops, the effect of job mobility, while already very small, becomes insignificant, and the difference between technical and economic education is substantially reduced. The 1.5 percent wage difference between the internal and the external labour market is accounted for by including overeducation. $^{5}$

- Table 3 --

In Table 3 we present separate estimates for two parts of the firm, the one with the internal and the one with the external labour market. The difference between the Mincer specification and the ORU specification is quite interesting. With the Mincer specification, returns to schooling in the external labour market are more than double those in the internal labour market. This difference is large, but we have no reason for distrust: there are no outliers or other data irregularities that may explain it. If we estimate the ORU specification, the coefficients in the two segments are very similar. Hence, the Mincer specification gives a misleading indication of differences in rewards ${ }^{6}$.

\footnotetext{
${ }^{3}$ Indeed, if they eliminate all fixed effects they do get significant schooling effects at all job levels, and in fact also find returns to education increasing by job complexity as stressed by Hartog (1988).

${ }^{4}$ Our results also hold if we follow GBOR and include the mean level of wages by level of required education (results not reproduced here; see Groeneveld, 2002:197).

${ }^{5}$ We also have estimated the regression models separately by four age categories and the results are essentially unchanged. With the age composition of the company in mind, four categories are distinguished: up to 38, 39-46, 47-54, and older than 55 years. The coefficients for required education and for overeducation increase with age, as they pick up some of the age effect on wages.

${ }^{6} \mathrm{We}$ must admit we have been unable to find a convincing interpretation of this result. The difference cannot be explained as a composition effect. Weighting the regression coefficients from ORU by probabilities of over- and undereducation produces equal weighted returns (of about 0.06). In fact, the difference already disappears if we
} 
For the external labour market, again we find the key results. For the internal labour market, we find that the penalty on undereducation is no longer significant. It fits in with the general result in the literature that the effect of undereducation is quite small and not always significant. It also relates to an observation in Hartog (2000) that there appears some asymmetry in wage effects when information is unfolding about individuals' abilities: positive surprises in ability levels lead to higher wages and higher job levels, whereas individuals are insured against a reduction in income when they turn out below standard. Indeed, one might expect such insurance to be more prominent in an internal labour market than in an external labour market. By definition, an internal labour market is sheltered from outside forces, and much is determined by rules and procedures rather than market pressures (compare Dolton and Vignoles, 2000). The external labour market at the time of our sample was subject to strong labour demand pressures, which also makes it understandable that the external labour market exhibits more response to over- and undereducation. Market pressure also explains why returns are higher in the external than in the internal labour market. The wage pressure is not unevenly distributed by age, however: age earnings profiles are not significantly different between the two labour markets. The number of previous jobs held within the firm is significant in the internal labour market. Perhaps surprisingly, the effect is negative. It might relate to workers who have a hard time finding a good match. The effect is very small however: it takes five additional job moves to loose one percent in gross wages .

\section{$4 \quad$ Overeducation as an investment?}

As noted, there is no uniformly accepted theory to explain the ORU findings. Similarly, there is no generally accepted theory to explain careers within organisations. But as Gibbons and Waldman (1999) note, in spite of the new approaches, human capital theory is still one of the building block models. Proponents of human capital theory argue that overeducated workers have deliberately selected the job for which they are overqualified because it provides them with above average investment opportunities (Sicherman, 1991; Robst, 1995; Van

Gameren, 2000). ${ }^{7}$ The implication put to test, by Sicherman (1991), Robst (1995) and Büchel and Mertens (2000), is that overeducated workers experience superior career development as their investment pays off. Sicherman (1991) finds indeed that overeducated workers are more likely to be promoted to a higher job level

move from actual to required education as explanatory variable. We thus anticipated that if we estimate a regression equation with attained education explained from required education, the slope in the internal market must be larger than in the external market, but his turns out not to be the case. 
than adequately educated workers, but so are undereducated workers. Robst (1995) finds that the overeducated are more likely and the undereducated are less likely to be promoted. Büchel and Mertens (2000) consider wage growth rather than job level and find that overeducated workers are less likely and undereducated workers are more likely to experience above average wage growth.

We will analyse both job promotion and wage growth for our sample of workers within a single firm, and test the hypothesis of future benefits from present overeducation. We use the observations of workers employed in 1995 and in 1998 and for whom the job title is known $(\mathrm{N}=2719)$. Workers who entered after 1995 or who left before 1998 have been excluded. We also excluded 15 workers who had reached the highest job scale in 1995 and for whom promotion was impossible. That leaves us with a sample of 2704 (compare Table 1).

In accordance with the literature on overeducation and promotions we use two measures for career development, job promotion and wage growth. Job level and wage declines are so rare that we ignore them. Job promotion, measured with a dummy, is defined as an increase in job scale between 1995 and 1998. Job scales are ranked from 1 (unskilled) to 14 (academic, management). Excess or relative wage growth is also measured with a dummy, identifying cases where wage growth between 1995 and 1998 is at least one standard deviation higher than the average wage growth for employees who are in the same job scale in 1995. Note that by measuring promotion and excess wage growth with dummies we test a strong version of the investment theory, with truly marked effects on careers. As before, wage is defined as gross monthly wage at full-time equivalent. Job scales are related to pay scales but they are not identical. Moreover, pay scales have a substantial overlap. About one in five employees makes a promotion to a higher job scale. About 15 percent has excess wage growth as defined above, i.e. surpassing the mean by at least one standard deviation. Job promotion and excess wage growth correlate at 0.30. Among non-promoted employees 90 percent neither experiences excess wage growth. Among promoted employees, 37 percent also has excess wage growth.

- Table 4 --

- Table 5 --

\footnotetext{
${ }^{7}$ This, of course, cannot explain a higher wage than in a job that just requires the attained level of education if individuals have to pay (in part) for their training.
} 
Results are given in Tables 4 and 5. Explanatory variables are measured in 1995. The two models only differ in using attained or requi red education as point of reference. Since this has barely visible effect on the coefficients of the other variables, we only report them once. Limitations of our analysis are obvious. We only have a small window of observation. We restrict the analysis to internal mobility, as we do not know new wage or job title of those who left. This is potentially a serious limitation of our study. At this stage we simply cannot assess how selective quit behaviour may be. Perhaps the effect should not be overrated. As we noted earlier, of those who left between 1995 and 1998, 25 percent were overeducated, as against 19 percent of those who stayed. For undereducation, the share was 12 percent among those who left and 14 percent among those who stayed. We return to the is sue in the concluding section.

In the specification with attained education instead of required education as a regressor (Model 2), we find that overeducation significantly improves the probability of job promotion but has no effect on excess wage growth. ${ }^{8}$ Undereducation has negative effects but they are not statistically significant (Table 4). As Table 5 indicates, the results are similar at the internal labour market, but with the undereducation effect also significant for job promotion. At the external labour market, however, all effects are insignificant, which may be partly due to the relatively small number of observations. Using required education instead of attained education (Model 1) gives similar results. In the aggregate estimation (Table 4), we see that overeducation significantly enhances career development, but at a decreasing rate. Both the probability of job promotion and of excess wage growth is higher for the overeducated, but mainly so at young ages: the interaction effect with age is negative. Undereducation has no significant effects. When we estimate separately for the two markets, we find that at the external labour market there are virtually no effects (except for a significant effect of overeducation on job promotion). In the internal labour market, we find results highly similar to the overall effect. Now, undereducation effects on job promotion are also significant. In fact, all over- and undereducation effects on job promotion are significant at 5 percent or better.

So, we may conclude that at the internal labour market, overeducation significantly boosts career development at young age, both in terms of job promotion and excess wage growth. Undereducation has a similar negative effect on job promotion but not on excess wage growth. At the firm's exposed external labour market, we do not find these effects.

\footnotetext{
${ }^{8}$ Age squared is not included because of high multicolinearity.
} 
We have established unequivocal support for the ORU specification of the wage function for employees of a single firm, with required education measured from the firm's hiring standards. In fact, this latter measure strongly improves the quality of the fit. The usual wage effects of required education, over - and undereducation are also found for this single firm. Thus, the conclusion put forward by GBOR (2002) that a positive effect of overeducation on wages is mainly due to firm fixed effects (a conclusion we have some econometric reservations about), can be confronted with our finding that results within a single firm mirror the effects found in market cross-sections. Selection of overeducated workers into high wage firms, if found at all, is certainly not the exclusive explanation for the positive wage effect of overeducation. Our results essentially hold for both markets that we have distinguished within the firm, the sheltered internal labour market and the exposed external labour market.

In the firm's internal labour market we find that overeducation improves career development in terms of job promotion and undereducation hurts it. Both effects diminish with the age at which the worker is observed to be over- or undereducated. In this segment, excess wage growth is boosted by overeducation, again at a rate diminishing with age. In the external segment, we only find a positive effect of overeducation on job promot ion; all other effects on promotion and excess wage growth are insignificant. Hence, the claim made by human capital theory proponents that being overeducated for a job points to selecting a position with exceptional investment opportunities that pay off later does not find much support in the context of an individual firm.

We have been unable to test the effect of over-and undereducation on outside opportunities, as we have no information on the new job of those who left. In our data, the incidence of overeducation is higher among job quitters than among stayers, while the incidence of undereducation is equal. This is in line with Alba-Ramirez' (1993) results for Spain and Sicherman's (1991) results for the USA that job turnover among overeducated is higher than for properly matched workers, while for undereducated workers there is no difference. On the effect of overeducation on wage growth for movers only, isolated from effects for stayers, there is no evidence available in the literature. This remains for future work, as neither Alba-Ramirez nor Sicherman have addressed this issue. 


\section{References}

Alba-Ramirez, A. (1993). Mismatch in the Spanish Labor Market? Journal of Human Resources. XXVIII. 2. 259278.

Büchel, F. \& A. Mertens (2000). Overeducation, under education, and the theory of career mobility. Berlin: Max Planck Institute for Human Development (paper presented at EALE/SOLE Conference 2000, Milan, June 22$25,2000)$.

Daley, M.C., F. Büchel \& G. Duncan (2000). Premiums and penalties for surplus and deficit education, evidence from the United States and Germany. Economics of Education Review. 19. 2. 169-178.

Dolton, P. \& A. Vignoles (2000). The incidence and effects of overeducation in the U.K. graduate labour market. Economics of Education Review. 19. 2. 179-198.

Gameren, E. van (2000). The Internal Economics of Firms. An Investigation into the Labour Mobility within Firms. Amsterdam: proefschrift Vrije Universiteit.

Garen, J. (1988). Empirical studies of the job matching hypothesis. Research in Labor Economics. 9. 187-224.

Gautier, P.A., G.J van den Berg, J.C. van Ours, \& G. Ridder (1998). Worker turnover at the firm level and crowding out of lower educated workers. Den Haag: Netherlands Bureau for Economic Policy Analysis (Research Memorandum 144).

Gaut ier, P.A., G.J van den Berg, J.C. van Ours, \& G. Ridder (2002). Worker turnover at the firm level and crowding out of lower educated workers. European Economic Review. 46. 523-538.

Gibbons, R. \& M. Waldman (1999). Careers in organizations. Ashenfelter, O. \& D. Card. Handbook of Labor Economics. Amsterdam: North-Holland. Chapter 36.

Groeneveld, S.M. (2002). Loopbanen onder de loep. Allocatie en promotiekansen van werknemers van een organisatie in verandering. Assen: Van Gorcum [A Close Look At Careers. Employees' Allocation and Career Mobility in a Changing Organisation].

Groot, W. \& H. Maassen van den Brink (2000). Overeducation in the labor market: a meta-analysis. Economics of Education Review. 19. 2. 149-158.

Hartog, J. (1988). An ordered response model for allocation and earnings. Kyklos. 41. 1. 113-141.

Hartog, J. (2000a). Overeducation and earnings. Where are we, where should we go? Economics of Education Review. 19. 2. 131-147.

Hartog, J. (2000b). On returns to education: wandering along the hills of ORU land. Heijke, H. \& J. Muysken (eds). Education and training in a knowledge-based society. Houndmills: Macmillan Press. 
Hartog, J. \& H. Oosterbeek (1988). Education, allocation and earnings in The Netherlands: overschooling? Economics of Education Review. 7. 2. 185-194.

Robst, J. (1995). Career Mobility, Job Match, and Overeducation. Eastern Economic Journal. 21. 539-550.

Sicherman, N. (1991). 'Overeducation’ in the labor market. Journal of Labor Economics . 9. 2. 101-122. 
Tables

Table 1: Desciptive statistics (means, standard deviations between brackets)

\begin{tabular}{lcccc}
\hline & Internal labour market & External labour market & Other & Total \\
& $\mathrm{N}=1578$ & $\mathrm{~N}=406$ & $\mathrm{~N}=720$ & $\mathrm{~N}=2704$ \\
\hline Age & $43.6(8.1)$ & $41.8(7.8)$ & $43.6(7.7)$ & $43.3(8.0)$ \\
Tenure & $18.6(8.1)$ & $7.9(9.4)$ & $15.3(9.4)$ & $16.1(9.4)$ \\
Wage 1998 (gross Dfl/month) & $5232(949)$ & $5448(1282)$ & $5578(1307)$ & $5356(1118)$ \\
Wage 1995 (gross Dfl/month) & $4689(874)$ & $4840(1191)$ & $4986(1173)$ & $4791(1020)$ \\
Promoted 1995-1998 & $.14(.34)$ & $.34(.47)$ & $.23(.42)$ & $.19(.39)$ \\
Relative wage growth 1995-1998 & $.13(.34)$ & $.21(.41)$ & $.15(.36)$ & $.15(.36)$ \\
Required education (years) 1998 & $11.1(2.0)$ & $11.6(2.6)$ & $11.7(2.5)$ & $11.3(2.2)$ \\
Required education (years) 1995 & $11.9(1.6)$ & $11.9(2.2)$ & $12.1(2.1)$ & $11.9(1.8)$ \\
Education (years) 1998 & $11.9(1.5)$ & $12.6(1.6)$ & $12.6(1.9)$ & $12.2(1.7)$ \\
Education (years) 1995 & $11.8(1.5)$ & $12.5(1.6)$ & $12.6(2.0)$ & $12.1(1.7)$ \\
Overeducation (\%) 1998 & 13.4 & 30.2 & 21.0 & 18.0 \\
Overeducation (\%) 1995 & 15.3 & 32.2 & 22.3 & 19.2 \\
Undereducation (\%) 1998 & 16.6 & 13.7 & 10.8 & 14.6 \\
Undereducation (\%) 1995 & 16.7 & 11.0 & 9.9 & 14.3 \\
Number of positions & $3.8(3.0)$ & $3.9(2.7)$ & $4.5(3.1)$ & $4.0(3.0)$ \\
\hline
\end{tabular}

Note: 'Promoted' means promoted to a higher job rank. 'Relative wage growth' measures the proportion of workers with wage growth at least one standard deviation above the mean for workers initially in the same job scal e. 
Table 2: Overeducation, undereducation and wages (linear regression; dependent variable = $\ln ($ wage (gross/monthly; full time employment)); unstandardized coefficients and standard errors between brackets)

\begin{tabular}{|c|c|c|c|c|c|c|}
\hline \multirow[b]{2}{*}{ Constant } & \multicolumn{2}{|c|}{ Model 1} & \multicolumn{2}{|c|}{ Model 2} & \multicolumn{2}{|c|}{ Model 3} \\
\hline & $7.054^{\text {*** }}$ & $(.077)$ & $7.006^{* N * \pi}$ & $(.044)$ & $6.789^{* * * *}$ & $(.045)$ \\
\hline Female & $-.052^{* * *}$ & $(.009)$ & $-.042^{* * *}$ & $(.005)$ & $-.038^{* * * *}$ & $(.005)$ \\
\hline Age & $.032^{* * *}$ & $(.003)$ & $.024^{* * * *}$ & $(.002)$ & $.028^{* * * *}$ & $(.002)$ \\
\hline Age squared & $.000^{* * *}$ & $(.000)$ & $.000^{* * * *}$ & $(.000)$ & $.000^{* * * *}$ & $(.000)$ \\
\hline Education (years) & $.055^{* * *}$ & $(.002)$ & & & & \\
\hline Required education (years) & & & $.078^{\text {**** }}$ & $(.001)$ & $.087^{* * * *}$ & $(.001)$ \\
\hline Overeducation (years) & & & & & $.025^{* * *}$ & $(.002)$ \\
\hline Undereducation (years) & & & & & $-.003^{*}$ & $(.002)$ \\
\hline Number of courses & $.007^{* * *}$ & $(.001)$ & 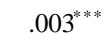 & $(.000)$ & $.003^{* * *}$ & $(.000)$ \\
\hline \multicolumn{7}{|l|}{ Field of study (other = ref.cat.) } \\
\hline - Technical & $-.045^{* * *}$ & $(.009)$ & $-.020^{* * * *}$ & $(.005)$ & -.008 & $(.005)$ \\
\hline - Economic & .010 & $(.009)$ & .005 & $(.005)$ & $.014^{* * *}$ & $(.005)$ \\
\hline \multicolumn{7}{|l|}{ Market (other $=$ ref.cat.) } \\
\hline - Internal & $-.015^{*}$ & $(.007)$ & $-.022^{* * * *}$ & $(.004)$ & $-.012^{* *}$ & $(.004)$ \\
\hline - External & $-.031^{* * *}$ & $(.009)$ & $-.012^{*}$ & $(.005)$ & $-.012^{*}$ & $(.005)$ \\
\hline Number of positions & $-.003^{*}$ & $(.001)$ & -.001 & $(.001)$ & -.001 & $(.001)$ \\
\hline $\mathrm{R}^{2}$ (adjusted) & \multicolumn{2}{|c|}{$.457^{\prime \prime}$} & \multicolumn{2}{|c|}{$.792^{\prime \prime}$} & \multicolumn{2}{|c|}{$.805^{7}$} \\
\hline $\mathrm{N}$ & \multicolumn{2}{|c|}{2827} & \multicolumn{2}{|c|}{2874} & \multicolumn{2}{|c|}{2782} \\
\hline
\end{tabular}

$*=\mathrm{p}<.05 ; * *=\mathrm{p}<.01 ; * * *=\mathrm{p}<.001$ 

Table 3: Market segments, overeducation, undereducation and wages (linear regression; dependent variable = ln(wage (gross/monthly; full time employment)); unstandardized coefficients and standard errors between brackets)

\begin{tabular}{|c|c|c|c|c|c|c|c|c|c|c|c|c|}
\hline \multirow[b]{3}{*}{ Constant } & \multicolumn{6}{|c|}{ Internal labour market } & \multicolumn{6}{|c|}{ External labour market } \\
\hline & \multicolumn{2}{|c|}{ Model 1} & \multicolumn{2}{|c|}{ Model 2} & \multicolumn{2}{|c|}{ Model 3} & \multicolumn{2}{|c|}{ Model 1} & \multicolumn{2}{|c|}{ Model 2} & \multicolumn{2}{|c|}{ Model 3} \\
\hline & $7.35^{* * * *}$ & $(.092)$ & $7.00^{3 * * *}$ & $(.056)$ & $6.84^{* * * 3}$ & $(.059)$ & $6.80^{* * * *}$ & $(.215)$ & $6.99^{3 * * *}$ & $(.116)$ & $6.68^{* * * *}$ & $(.116)$ \\
\hline Female & $-.061^{* * *}$ & $(.011)$ & $-049^{* * * *}$ & $(.007)$ & $-.046^{* * *}$ & $(.007)$ & -.032 & $(.027)$ & $-.032^{*}$ & $(.015)$ & $-.029^{*}$ & $(.014)$ \\
\hline Age & $.031^{* * * *}$ & $(.004)$ & $.025^{* * *}$ & $(.003)$ & $.028^{* * *}$ & $(.003)$ & $.036^{* * *}$ & $(.010)$ & $.027^{* * *}$ & $(.006)$ & $.032^{* * *}$ & $(.005)$ \\
\hline Age squared & $.000^{* * * *}$ & $(.000)$ & $.000^{* * *}$ & $(.000)$ & $.000^{* * *}$ & $(.000)$ & $.000^{* *}$ & $(.000)$ & $.000^{* * *}$ & $(.000)$ & $.000^{* * *}$ & $(.000)$ \\
\hline Education (years) & $.030^{* * * *}$ & $(.003)$ & & & & & $.067^{* * * *}$ & $(.005)$ & & & & \\
\hline Required education (years) & & & $.074^{* * *}$ & $(.001)$ & $.080^{* * *}$ & $(.002)$ & & & $.075^{* * *}$ & $(.002)$ & $.089^{* * *}$ & $(.003)$ \\
\hline Overeducation (years) & & & & & $.022^{* * *}$ & $(.002)$ & & & & & $.031^{* * *}$ & $(.004)$ \\
\hline Undereducation (years) & & & & & .002 & $(.002)$ & & & & & $-.010^{*}$ & $(.005)$ \\
\hline Number of courses & $.011^{* * *}$ & $(.001)$ & $.006^{* * *}$ & $(.001)$ & $.005^{* * *}$ & $(.001)$ & $.004^{* *}$ & $(.001)$ & $.002^{* *}$ & $(.001)$ & .001 & $(.001)$ \\
\hline \multicolumn{13}{|c|}{ Field of study (other = ref.cat.) } \\
\hline - Technical & $-.039^{* * * *}$ & $(.010)$ & $-.019^{* *}$ & $(.006)$ & -.010 & $(.007)$ & $-.053^{*}$ & $(.023)$ & -.015 & $(.013)$ & -.008 & $(.013)$ \\
\hline - Economic & $.015^{* * * *}$ & $(.011)$ & $.015^{*}$ & $(.007)$ & $.020^{* *}$ & $(.007)$ & .015 & $(.024)$ & .003 & $(.014)$ & .005 & $(.013)$ \\
\hline Number of positions & -.005 & $(.001)$ & $-.002^{*}$ & $(.001)$ & $-.002^{*}$ & $(.001)$ & .001 & $(.003)$ & .003 & $(.002)$ & .003 & $(.002)$ \\
\hline $\mathrm{R}^{2}$ (adjusted) & \multicolumn{2}{|c|}{$.406^{* * *}$} & \multicolumn{2}{|c|}{$.751^{* * * *}$} & \multicolumn{2}{|c|}{$.761^{* * *}$} & \multicolumn{2}{|c|}{$.464^{* * *}$} & \multicolumn{2}{|c|}{$.812^{* * *}$} & \multicolumn{2}{|c|}{$.834^{* * * *}$} \\
\hline $\mathrm{N}$ & \multicolumn{2}{|c|}{1599} & \multicolumn{2}{|c|}{1618} & \multicolumn{2}{|c|}{1584} & \multicolumn{2}{|c|}{467} & \multicolumn{2}{|c|}{470} & \multicolumn{2}{|c|}{461} \\
\hline
\end{tabular}

$*=\mathrm{p}<.05 ; * *=\mathrm{p}<.01 ; * * * \mathrm{p}<.001$ 
Table 4: Overeducation, undereducation and promotions (logistic regression; logit-effects and standard errors between brackets)

\begin{tabular}{|c|c|c|c|c|c|c|c|c|}
\hline \multirow[b]{3}{*}{ Constant } & \multicolumn{4}{|c|}{ Job shift } & \multicolumn{4}{|c|}{ Relative wage growth } \\
\hline & \multicolumn{2}{|c|}{ Model 1} & \multicolumn{2}{|c|}{ Model $2^{4}$} & \multicolumn{2}{|c|}{ Model 1} & \multicolumn{2}{|c|}{ Model $2^{\mathrm{A}}$} \\
\hline & .214 & $(.710)$ & & & $3.181 * * *$ & $(.851)$ & & \\
\hline Female & $-.570 * *$ & $(.191)$ & & & -.198 & $(.207)$ & & \\
\hline Age & $-.039 * * *$ & $(.010)$ & & & $-.206^{* * *}$ & $(.014)$ & & \\
\hline Required education (years) & -030 & $(.045)$ & & & $.286^{* *}$ & $(.053)$ & & \\
\hline Education (years) & & & -.030 & $(.045)$ & & & $.286^{* *}$ & $(.053)$ \\
\hline Overeducation (years) & $.940^{* * *}$ & $(.223)$ & $.970 * * *$ & $(.221)$ & $.880^{*}$ & $(.425)$ & .594 & $(.421)$ \\
\hline Undereducation (years) & -.528 & (.429) & -.558 & $(.430)$ & -.480 & $(.347)$ & -.194 & $(.352)$ \\
\hline Overeducation*age & $-016^{* *}$ & $(.005)$ & & & $-.029 *$ & $(.013)$ & & \\
\hline Undereducation*age & .009 & (.009) & & & .013 & (008) & & \\
\hline Number of courses & $.028^{*}$ & (.013) & & & -.005 & $(.016)$ & & \\
\hline \multicolumn{9}{|l|}{ Field of study (other=ref.cat.) } \\
\hline - $\quad$ Technical & -.266 & $(.175)$ & & & .046 & $(.223)$ & & \\
\hline - Economic & .228 & $(.181)$ & & & .159 & $(.222)$ & & \\
\hline \multicolumn{9}{|l|}{ Market (other = ref. cat.) } \\
\hline - Internal & $-.307^{*}$ & $(.138)$ & & & -.103 & $(.176)$ & & \\
\hline - External & .304 & $(.180)$ & & & .245 & $(.235)$ & & \\
\hline Number of positions & .032 & $(.021)$ & & & -.058 & $(.030)$ & & \\
\hline $\mathrm{Chi}^{2}$ & \multicolumn{4}{|c|}{$206.51 * * *$} & \multicolumn{4}{|c|}{$479.85^{* * * *}$} \\
\hline Df & \multicolumn{4}{|c|}{13} & \multicolumn{4}{|c|}{13} \\
\hline-2 Log likelihood & \multicolumn{4}{|c|}{1958.880} & \multicolumn{4}{|c|}{1369.930} \\
\hline $\mathrm{N}$ & \multicolumn{4}{|c|}{2351} & \multicolumn{4}{|c|}{2356} \\
\hline
\end{tabular}

$* \quad=\mathrm{p}<.05 ; * *=\mathrm{p}<.01 ; * * *=\mathrm{p}<.001$

a The omitted coefficients are virtually identical to those in Model 1 (except for required education) 
Table 5: Market segments, overeducation, undereducation and promotions (logistic regression; logit effects and standard errors between brackets)

\begin{tabular}{|c|c|c|c|c|c|c|c|c|c|c|c|c|c|c|c|c|}
\hline \multirow[b]{4}{*}{ Constant } & \multicolumn{8}{|c|}{ Internal labour marktet } & \multicolumn{8}{|c|}{ External labour market } \\
\hline & \multicolumn{4}{|c|}{ Job shift } & \multicolumn{4}{|c|}{ Relative wage growth } & \multicolumn{4}{|c|}{ Job shift } & \multicolumn{4}{|c|}{ Relative wage growth } \\
\hline & \multicolumn{2}{|c|}{ Model 1} & \multicolumn{2}{|c|}{ Model $2^{a}$} & \multicolumn{2}{|c|}{ Model 1} & \multicolumn{2}{|c|}{ Model $2^{\mathrm{a}}$} & \multicolumn{2}{|c|}{ Model 1} & \multicolumn{2}{|c|}{ Model $2^{\mathrm{a}}$} & \multicolumn{2}{|c|}{ Model 1} & \multicolumn{2}{|c|}{ Model $2^{\mathrm{a}}$} \\
\hline & .72 & $(1.072)$ & & & 2.26 & $(1.163)$ & & & $-3.65^{*}$ & $(1.805)$ & & & 1.89 & $(2.049)$ & & \\
\hline Female & -.380 & $(.258)$ & & & -.061 & $(.267)$ & & & $-1.21^{*}$ & $(.582)$ & & & -.035 & $(.561)$ & & \\
\hline Male & $-.037 * *$ & $(.013)$ & & & $-.200 * * *$ & $(.018)$ & & & .010 & $(.028)$ & & & $-.159 * * *$ & $(.036)$ & & \\
\hline Required education (years) & -.079 & $(.078)$ & & & $.312 * *$ & $(.085)$ & & & .017 & $(.117)$ & & & .254 & $(1.141)$ & & \\
\hline Education (years) & & & -.079 & $(.078)$ & & & $.321 * * *$ & $(.085)$ & & & .017 & (.117) & & & .254 & $(.141)$ \\
\hline Overeducation (years) & $1.08 * *$ & & $1.16^{* * *}$ & (.304) & $1.53^{*}$ & $(.733)$ & 1.22 & $(.729)$ & $1.06^{*}$ & $(.528)$ & 1.04 & (.538) & .418 & $(.825)$ & .165 & $(.831)$ \\
\hline Undereducation (years) & $-1.19 *$ & & $-1.27 *$ & (.540) & -.531 & $(.389)$ & -.218 & $(.402)$ & 2.08 & $(1.417)$ & 2.10 & $(1.407)$ & -.523 & $(1.211)$ & -.270 & (1.197) \\
\hline Overeducation*age & $-.018^{*}$ & $(.007)$ & & & $-.051^{*}$ & $(.023)$ & & & -.021 & $(.013)$ & & & -.017 & $(.024)$ & & \\
\hline Undereducation*age & .023 & $(.011)$ & & & .016 & $(.009)$ & & & -.051 & $(.032)$ & & & .007 & $(.027)$ & & \\
\hline Number of courses & $-.054^{*}$ & $(.025)$ & & & -.018 & $(.027)$ & & & $.100 * * *$ & $(.027)$ & & & -.008 & $(.027)$ & & \\
\hline \multicolumn{17}{|l|}{ Field of study (other=ref.cat.) } \\
\hline - $\quad$ Technical & -.066 & $(.249)$ & & & .396 & (.306) & & & .429 & $(.529)$ & & & .186 & $(.662)$ & & \\
\hline - Economic & .104 & $(.263)$ & & & .305 & $(.310)$ & & & $1.22^{*}$ & $(.545)$ & & & 1.22 & $(.641)$ & & \\
\hline Number of positions & .037 & $(.031)$ & & & -.047 & $(.040)$ & & & .087 & $(.061)$ & & & -.117 & $(.081)$ & & \\
\hline $\mathrm{Chi}^{2}$ & \multicolumn{4}{|c|}{$122.62 * * *$} & \multicolumn{4}{|c|}{$293.12 * * *$} & \multicolumn{4}{|c|}{$74.63^{* * * *}$} & \multicolumn{4}{|c|}{$61.83^{* * *}$} \\
\hline Df & \multicolumn{4}{|c|}{11} & \multicolumn{4}{|c|}{11} & \multicolumn{4}{|c|}{11} & \multicolumn{4}{|c|}{11} \\
\hline-2 Log likelihood & \multicolumn{4}{|c|}{1054.095} & \multicolumn{4}{|c|}{839.221} & \multicolumn{4}{|c|}{285.972} & \multicolumn{4}{|c|}{208.14} \\
\hline $\mathrm{N}$ & \multicolumn{4}{|c|}{1470} & \multicolumn{4}{|c|}{1472} & & 295 & & & & 25 & & \\
\hline
\end{tabular}

$*=\mathrm{p}<.05 ; * *=\mathrm{p}<.01 ; * * *=\mathrm{p}<.001 \quad{ }^{\mathrm{a}}$ The omitted coefficients are virtually identical to those in Model 1 (except for required education) 


\section{IZA Discussion Papers}

\begin{tabular}{|c|c|c|c|c|}
\hline No. & Author(s) & Title & Area & Date \\
\hline 869 & $\begin{array}{l}\text { A. B. Krueger } \\
\text { A. Mas }\end{array}$ & $\begin{array}{l}\text { Strikes, Scabs and Tread Separations: Labor } \\
\text { Strife and the Production of Defective } \\
\text { Bridgestone/Firestone Tires }\end{array}$ & 3 & 09/03 \\
\hline 870 & $\begin{array}{l}\text { S. Klasen } \\
\text { A. Launov }\end{array}$ & $\begin{array}{l}\text { Analysis of the Determinants of Fertility Decline } \\
\text { in the Czech Republic }\end{array}$ & 4 & 09/03 \\
\hline 871 & $\begin{array}{l}\text { Y. L'Horty } \\
\text { C. Rault }\end{array}$ & $\begin{array}{l}\text { The Impact of Growth, Labour Cost and Working } \\
\text { Time on Employment: Lessons from the French } \\
\text { Experience }\end{array}$ & 5 & 09/03 \\
\hline 872 & $\begin{array}{l}\text { J. R. Munch } \\
\text { M. Rosholm } \\
\text { M. Svarer }\end{array}$ & Are Home Owners Really More Unemployed? & 1 & 09/03 \\
\hline 873 & $\begin{array}{l}\text { M. Falk } \\
\text { B. M. Koebel }\end{array}$ & $\begin{array}{l}\text { The Impact of Office Machinery and Computer } \\
\text { Capital on the Demand for Heterogeneous } \\
\text { Labour }\end{array}$ & 5 & 09/03 \\
\hline 874 & J.-S. Pischke & $\begin{array}{l}\text { The Impact of Length of the School Year on } \\
\text { Student Performance and Earnings: Evidence } \\
\text { from the German Short School Years }\end{array}$ & 6 & 09/03 \\
\hline 875 & C. Grund & $\begin{array}{l}\text { Severance Payments for Dismissed Employees } \\
\text { in Germany }\end{array}$ & 3 & 09/03 \\
\hline 876 & $\begin{array}{l}\text { M. Karanassou } \\
\text { H. Sala } \\
\text { D. J. Snower }\end{array}$ & $\begin{array}{l}\text { The European Phillips Curve: Does the NAIRU } \\
\text { Exist? }\end{array}$ & 3 & 09/03 \\
\hline 877 & M.-S. Yun & Decomposing Differences in the First Moment & 3 & 09/03 \\
\hline 878 & $\begin{array}{l}\text { J. T. Addison } \\
\text { C. Schnabel } \\
\text { J. Wagner }\end{array}$ & $\begin{array}{l}\text { The Course of Research into the Economic } \\
\text { Consequences of German Works Councils }\end{array}$ & 3 & 09/03 \\
\hline 879 & $\begin{array}{l}\text { A. Constant } \\
\text { Y. Shachmurove }\end{array}$ & $\begin{array}{l}\text { Entrepreneurial Ventures and Wage Differentials } \\
\text { Between Germans and Immigrants }\end{array}$ & 1 & 09/03 \\
\hline 880 & $\begin{array}{l}\text { W. Koeniger } \\
\text { A. Vindigni }\end{array}$ & $\begin{array}{l}\text { Employment Protection and Product Market } \\
\text { Regulation }\end{array}$ & 2 & $10 / 03$ \\
\hline 881 & R. A. Hart & $\begin{array}{l}\text { Worker-Job Matches, Job Mobility, and Real } \\
\text { Wage Cyclicality }\end{array}$ & 1 & $10 / 03$ \\
\hline 882 & $\begin{array}{l}\text { A. Lindbeck } \\
\text { D. J. Snower }\end{array}$ & The Firm as a Pool of Factor Complementarities & 5 & $10 / 03$ \\
\hline 883 & $\begin{array}{l}\text { S. Groeneveld } \\
\text { J. Hartog }\end{array}$ & $\begin{array}{l}\text { Overeducation, Wages and Promotions within } \\
\text { the Firm }\end{array}$ & 5 & $10 / 03$ \\
\hline
\end{tabular}

An updated list of IZA Discussion Papers is available on the center's homepage www.iza.org. 